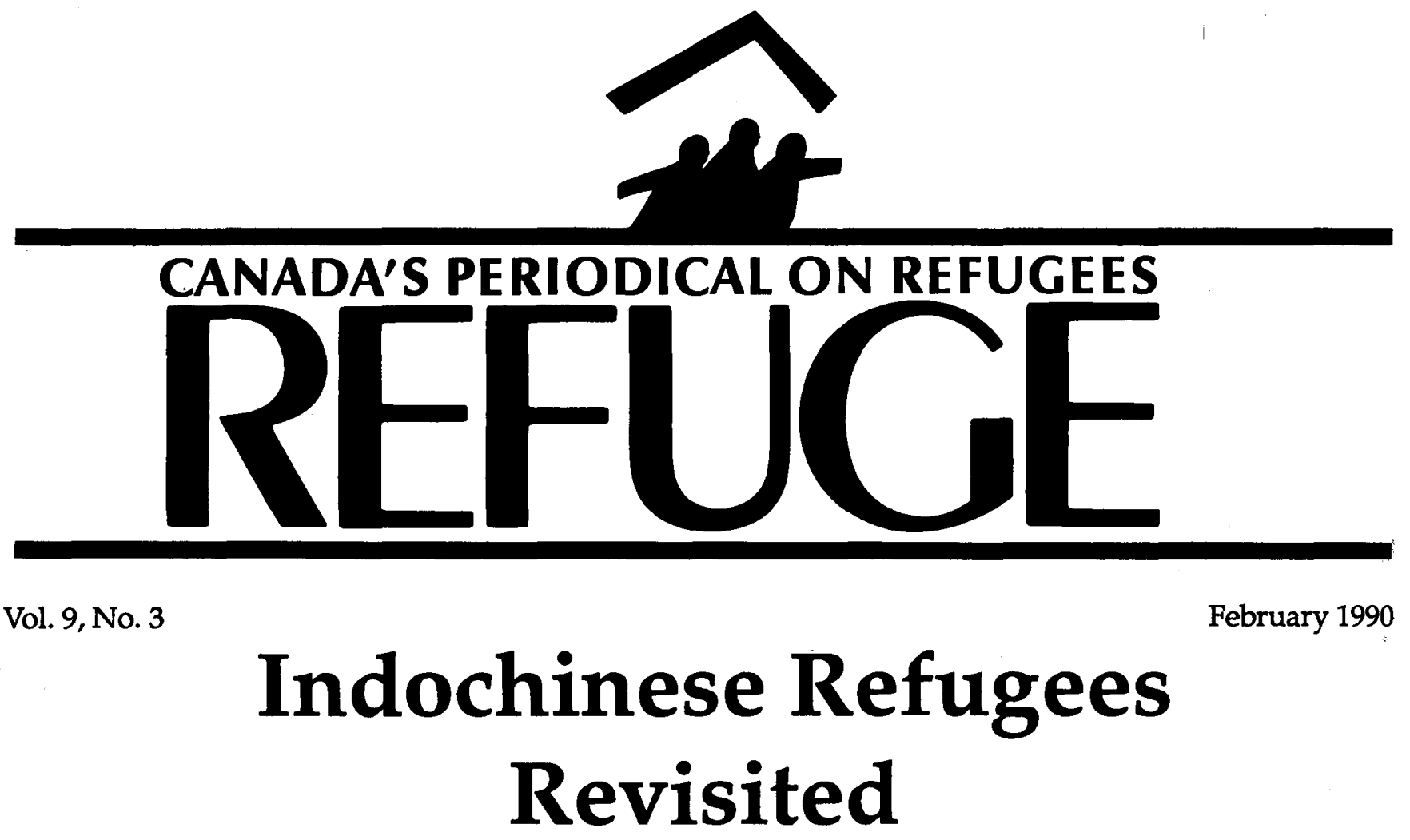

When Ho Chi Minh and his compatriots fought against French colonization in the middle of the 20th century, they might not have imagined that one day the big city of Southern Vietnam would bear Ho Chi Minh's name. They might also not have thought that their struggle would end up with the liberation and unification of the country, and that this phenomenon would chase hundreds of thousands of Vietnamese from the town which bears his name.

Actually, the war, famine and fear of the new socialist regime drove the Vietnamese, the Khmer and the Lao people to flee their homelands and thus they become refugees in many countries in the world. Over time, the profile of the refugees changed as did the reaction of the international

We regret the recent passing of Prof. Atle Grahl-Madsen, the internationally-renowned expert on refugee law. community towards those asylumseekers: from full humanitarian enthusiasm during the latter half of the 1970 s and the early 1980 s to a certain level of indifference or fatigue towards the assistance activities during the second half of the 1980s. Paradoxically, as soon as the compassion fatigue reached its peak in 1987, the socio-political conditions in Vietnam and in Laos seemed to improve. The governments of the two countries are trying to mend relations with countries of the nonsocialist world, especially in the economic and political spheres. Therefore, new hope for peace in Indochina is well-founded although the political situation in Cambodia is still unsettled. This expectation of peace should act to reduce the number of asylum-seekers from Vietnam and Laos. And repatriation should become a more realistic durable solution to the refugee problem.

The dynamism of the changing socio-political conditions of the Indochinese countries and its

Continued on page 2

\title{
IN THIS ISSUE:
}

NGO Services to Refugees/Displaced Persons in Thailand by Roger Fordham

page 4

Voluntary Repatriation of the Indochinese Refugees by Pierre Jambor

page 7

Mandatory Repatriation Is Not the Answer to Hong Kong's Problem by Leonard Davis

page 10

The Attitude of the Local Population Towards

Vietnamese Boat People in Hong Kong byLawrence Lam page 12

Political Pawns: Rrefugees on the

Thai-Kampuchean Border reviewed by Penny Van Esterick page 15 
implication for the refugee crisis has forced refugee assistance personnel in the UN and governmental as well as non-governmental organizations to reevaluate their role in the assistance activities, which has been to provide basic relief to refugees. Relief agencies should avoid involving themselves in partisan politics in the areas that have seen a large exodus of refugees. By sticking to their relief activities, refugee assistance personnel have kept

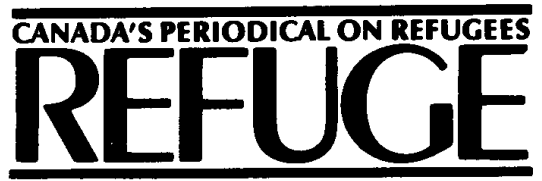

Centre for Refuge Studies, Yort Univentity, Suite 234, Administrative Studies Building, 4700 Keele Street, North Yodt, Ontario, Canada M3J 1 P3. Telephone: (416) 736-5663. Fax: (416) 736-5687. Electronic Mail Via Bitnet Addres: REFUGE@YORKVM1. their credibility. But if they now try to get involved in the politics of Indochina, their status would change and this.would complicate their endeavor vis-'a-vis the refugees. Roger Fordham of the Committee for Coordination of Services to Displaced Persons in Thailand (CCSDPT) in Bangkok emphasizes this fact in his article on NGO services to refugees in Thailand. Providing the best possible quality of life to the refugees should be the ultimate goal of concerned organizations

This issue of Refuge focuses on refugee repatriation, one of the several alternatives to resolve the complicated refugee problem. The articles contributed by Pierre Jambor, the UNHCR representative in Bangkok, and Leonard Davis, from the City Polytechnic of Hong Kong, are highly informative and thoughtful. The question is whether or not the refugees themselves have a right to choose to return if they have already decided to leave and accepted refugee status. Unfortunately, their decision is not the only one of consequence. The attitudes of the people of Hong Kong will help determine whether they are given that choice. Lawrence Lam's article describes those attitudes and analyzes the factors behind them.

In this decade, if Ho Chi Minh were still alive he might have been depressed about not having the chance to tell the world his expectations about the destiny of Indochina and the Indochinese people since others had said so many things already.

Khien Theeravit

Supang Chantavanich Guest Editors

\section{Guest Editors: \\ Khien Theeravit \\ Supang Chantavanich \\ Editor: \\ Howard Adelman \\ Executive Editor: \\ Alex Zisman \\ Circulation Manager: \\ Helen Gross \\ Assistant to the Circulation Manager: Ching Man (C.M.) Wong}

Refuge is dedicated to the encouragement of assistance to refugees by providing a forum for sharing information and opinion on Canadian and international issues pertaining to refugees. It is published four times a year by the Centre for Refugee Studies. It is a non-profit, independant periodical supported by private donations and by subscriptions. It is a forum for discussion, and the views expressed do not necessarily reflect those of its funders or staff.

All material in Refuge may be reproduced without permmision unless copyrighted or otherwise indicated. Credit should be given to the author or source, if named.

Subscription rates for one year are $\$ 20.00$ in Canada and US, $\$ 25.00$ overseas. Please enclose payment with your order.

\section{Logo Design:}

Dreadnought Co-operative Inc., Toronto

Layout:

Pages Plus, 131 Atkinson, York University

Second Class Mall Regibtration No 5512 ISSN $0229-5113$

\section{Sponsorships at Phanat Nikhom Refugee Camp}

The following letter was addressed by father Olivier, a jesuit priest working in Thailand, to private sponsors in Canada. Its relevance warrants sharing it with our readers.

In February 1989 I visited several groups and associations in Canada requesting that they open their hearts to the plight of refugees in this camp who so desperately need an infusion of hope in order to carry on. Many generously accepted to sponsor some of these refugees and their response was truly heart-warming. They went to work quickly to plan and organize these sponsorships, and I am sure they looked forward to the day of their refugees' arrival, well prepared to assist in their resettlement.

After all their efforts, some have heard that those people they were so eager to help have now been accepted to go to another country or will be coming to Canada under the DC1 (humanitarian) category. This will surely have caused some real frustration for some, and perhaps even a little disappointment.

Please allow me to make a few points of clarification regarding resettlement from Phanat Nikhom camp, in the hope that those involved might not lose faith in the process altogether:

1. A refugee falls under the protection of the international community through the auspices of the United Nations High Commission for Refugees (UNHCR). When this organization presents the refugee to a resettlement country, the refugee seldom refuses; the lack of choice in these matters characterizes the sort of poverty that is theirs. To refuse, especially if one has previously been rejected by other countries, is a sure ticket to a protracted stay in a camp.

2. Many of the people I presented were "long stayers" in Thai refugee camps, and the UNHCR tries every which way to secure permanent solutions for such cases. Consequently, until they have received some guarantee from a sponsor and from an embassy 
that a refugee has been accepted and will be resettled, the UNHCR staff will persue as many options as possible on behalf of the refugee family. Several months will usually pass before a decision is made to sponsor someone, before the necessary organization is set in place, the proper forms completed and submitted to the Immigration Department, the sponsorship notice sent to the embassy in Bangkok, and an interview finally arranged in the refugee camp. You will surely understand that, until I have obtained a definite confirmation that indeed a sponsorship has been secured, I cannot request of the UNHCR that they put on hold their efforts at finding a home for these people. During this "interim period," then, it does happen that the UNHCR presents to another country the refugee family people in Canada have been helping to resettle. The refugee often mentions that a sponsorship is being sought by father Olivier, but without the documents to prove it, he is not in a position to insist; that is why I have insisted that copies of the Canada Immigration sponsorship form be sent to me as soon as possible.

3. While it is true that the obtainment of a sponsorship will assure that the refugee will be granted an interview; there is no guarantee that the refugee will be accepted at that interview by the embassy staff. Also, it does happen that between Canada Immigration and Canada's embassy in Bangkok, communications become defective sometimes; Bangkok may not receive the notification that a sponsorship has been secured. In such situations, if I have a copy of the sponsorship form, I am able to alert the embassy about the problem. But, of course, during the interim, again the UNHCR is seeking alternatives for the refugee.

4. Occasionally, a particularly bold refugee will ask my help in searching for a sponsorship while not telling me that he has requested the same thing from others. It is hard for me to feel too much anger over such initiatives on the part of a desperate refugee, but I certainly do feel the upset and pain of people over these matters which leaves them feeling a little abused.
5. In June 1989 , a conference in Geneva determined what the distribution between countries would be of the 52,000 Vietnamese still in Asia who remain eligible for resettlement. Over the three years following the conference it was agreed that 22,000 would go to the USA, 11,000 to Canada, 11,000 to Australia, 4,400 to France, and 3,600 to Finland, Sweden, Norway, Japan, etc. Given these commitments, certain countries like the USA and Australia, who had previously rejected some Vietnamese refugees, are now reversing their decisions and agreeing to accept some of those with links in their countries; I think we pretty well have to surrender graciously to these decisions.

6. It is true that a refugee is in a position of powerlessness, usually, and enjoys few freedoms, especially if he or she has no relatives abroad. For these persons decisions on their fate are made in large measure by others. I have seen the disappointment and sadness of people in my office when having hoped for a sponsorship in Canada, they were accepted by another country before the arrival of the confirmation from Canada.

7. Since July 1989, the French, Australian and Canadian embassies have decided not to accept or interview most of those people who have close links in other countries (including parents, husbands or wifes, brothers and sisters, brothers-in-law or sisters-in-law, uncles, aunts, nephews and nieces). Thus, several people have been put on hold or rejected outright by Canada because their links now are relevant while previously they were less so.

8. I can quite appreciate, when it comes to those private sponsors concerned, the sense of having been betrayed in their generosity, and of so much work having gone down the drain. But refugees too can experience such deception and feel crushed when they not only are rejected to go to their communities, but are condemned to staying in a camp for several more years. I believe that in fact the decision to help a refugee family has not been for nought; the sponsors have shared in their suffering, they have felt something of the refugees' pain, of their struggle, of their frustrations. The private sponsors also have known well the failings of an administrative system that plods along very slowly. They should try to remember that while they have felt frustration in their long and apparently futile wait, thousands here continue to suffer also in their wait; ours is easier than theirs.

In the end the important thing is that the refugees will find a home somewhere. If they can achieve resettlement through our aid, we can be glad; and if they have managed to find another route to their freedom, surely we can rejoice in that too. Furthermore, I can assure the private sponsors that their efforts do not need to remain fruitless. Can you imagine the joy experienced when I am able to announce that a sponsorship has been found! The private sponsors have offered so much in renewed hope, in rekindling the refugees' will to go on, and I assure you that this gift to refugees is a very significant one.

Let me finish by reminding you that refugees, as well as those like myself trying to assist them, desperately need your continued assistance. Even if together we do not achieve the intended goal of resettling a particular family, the generosity, friendship, and your hard work are essential to us. Every day we witness such despair and sadness here; please don't give up, ... please ask for another case or profile ... another family is always waiting for a chance to resettle.

Justice in this world is not an easy goal to achieve; much slow, painstaking work and a great deal of perseverance are necessary, as you know. Even if I do not know all of you personally, I am often with you in spirit, remembering your commitment, your courage and your generosity for which I am sure God will reward you. I thank you from the bottom of my heart.

With warm regards,

Father Olivier, s.j.

St. Louis Hospital

215 Sathorn Tai $R d$.

Bangkok 12

Thailand 